\begin{abstract}
Iranica
Abstracta Iranica Revue bibliographique pour le domaine irano-aryen

Volume 34-35-36 | 2017

Comptes rendus des publications de 2011-2013
\end{abstract}

\title{
Adam Carter McCollum. The Story of Mar Pinhas
}

\section{Christelle Jullien}

\section{(2) OpenEdition \\ Journals}

Édition électronique

URL : http://journals.openedition.org/abstractairanica/41270

DOI : 10.4000/abstractairanica.41270

ISSN : 1961-960X

Éditeur :

CNRS (UMR 7528 Mondes iraniens et indiens), Éditions de l'IFRI

Référence électronique

Christelle Jullien, «Adam Carter McCollum. The Story of Mar Pinhas », Abstracta Iranica [En ligne], Volume 34-35-36 | 2017, document 2, mis en ligne le 15 juillet 2016, consulté le 27 septembre 2020.

URL : http://journals.openedition.org/abstractairanica/41270 ; DOI : https://doi.org/10.4000/ abstractairanica. 41270

Ce document a été généré automatiquement le 27 septembre 2020.

Tous droits réservés 


\title{
Adam Carter McCollum. The Story of Mar Pinhas
}

\author{
Christelle Jullien
}

\section{RÉFÉRENCE}

Adam Carter McCollum. The Story of Mar Pinhas. Piscataway, Gorgias Press, 2013, 62 p. (Persian Martyr Acts in Syriac: Text and Translation 2)

$1 \quad$ La Vie syriaque de Mār Pinḥas (BHO 989) est ici livrée en traduction anglaise. Nous ne la connaissions que dans sa version syriaque éditée par Paul Bedjan en 1894 au $4^{\mathrm{e}}$ tome de ses Acta martyrum et sanctorum syriace (p. 208-218). Le texte hagiographique n'est pas daté mais participe du contexte de la persécution du roi sassanide Šābuhr II (309-379). Il s'agit d'une élaboration bien postérieure à la mort du protagoniste qui a pour finalité de développer et de renforcer le culte du martyr : l'auteur anonyme y évoque d'ailleurs les reliques du saint. Une introduction et des annotations permettent d'expliciter des passages et les intentions d'écriture : faible historicité à accorder au récit, éléments de topographie, quelques détails de codicologie. La version arabe publiée par A. Scher dans son Kitāb sīrat ašhar šuhadā’ al-mašriq al-qiddīsin (Mossoul en 1900-1906) est également donnée à titre comparatif.

\section{AUTEURS}

CHRISTELLE JULLIEN

CNRS, Mondes iranien et indien, Paris 